
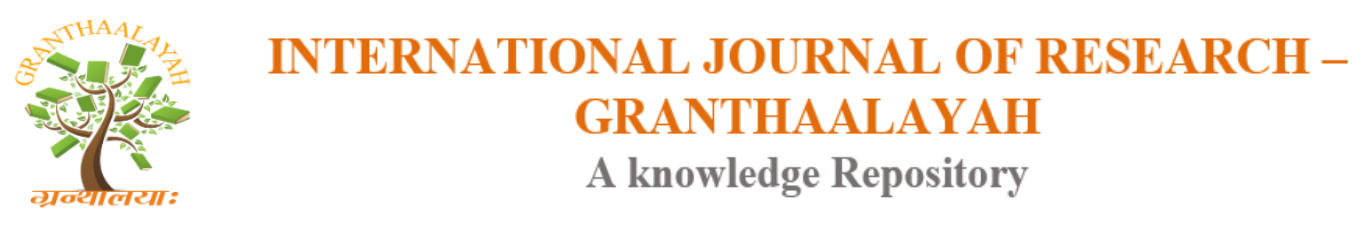

Social

\title{
CRITICAL AND CREATIVE THINKING OF TEACHER TRAINEES
}

\author{
Tomšik R. *1, Gatial V. ${ }^{1}$, Verešová M. ${ }^{1}$, Čičová, A. ${ }^{1}$ \\ ${ }^{* 1}$ Department of Educational and School Psychology, Faculty of Education, Constantine the \\ Philosopher University in Nitra, Slovakia
}

\begin{abstract}
The paper offers an initial theoretical insight into critical and creative thinking constructs (tools), as well as it provides the theoretical and empirical evidence of the relationship between mentioned variables and their level in specific populations. The main objective is to verify differences in critical and creative thinking of teacher trainees within the region schools, considering their fields of study. Critical thinking has been mapped by W-GSTA questionnaire and for creative thinking has been applied Test for Creative Thinking - Drawing Production (TCT-DP). The sample consisted of 317 teacher trainees studying single-subject study programmes (humanities or natural sciences) or two-subject study in combination. Statistical analyses have revealed the significant difference in the rate of critical and creative thinking. Particularly, teacher trainees of two-subject study in combination have achieved significantly higher results in a critical thinking in comparison with teacher trainees studying humanities. On the other hand, teacher trainees of natural sciences have achieved higher results in a creative thinking in comparison with students of humanities.
\end{abstract}

Keywords: Critical Thinking; Creative Thinking; Teacher; Teacher Trainees.

Cite This Article: Tomšik R., Gatial V., Verešová M., Čičová, A.. (2018). "CRITICAL AND CREATIVE THINKING OF TEACHER TRAINEES." International Journal of Research Granthaalayah, 6(9), 148-155. https://doi.org/10.5281/zenodo.1436786.

\section{Introduction}

Since students and pupils are surrounded by a great amount of information from different sources, demands on their cognitive functions have been increasing. This fact is a reason why a student's, and also teacher's, ability to think critically has been emphasized in education. Petrasová (2009, p. 7), for instance, states that a term critical thinking has been applied in an education field for decades and some significant educators call it as "a higher" way of thinking, representing "a set of thought processes that starts with some information and finishes with a decision". Based on the National Programme of Education in the Slovak Republic, the critical (as well as creative) thinking is considered the key competence of each individual. In particular, it is "an ability to solve problems in both critical and creative ways, to identify them, to analyse, to propose solutions, to offer feedback and evaluate them, and finally to learn from them" (Projekt Milénium, 1998, p. 18). Applying critical thinking in the learning process, both in student's and teacher's work, is 
perceived in our country as a certain step forward - the path to active work of students, their interest in curriculum, and motivation to learn. It is not just the process of education itself but a forming students' personality, preparation for being and self-realization (Hajrová, 2015). Moreover, a critical thinking (and a learning process) is demanding for non-traditional approaches applied mainly from the teacher's point of view to students. Authors like Zelina (1996), Čáp \& Mareš (2001), Maňák \& Švec (2003), Turek (2008) emphasize the strong formal influence of a teacher on his/her students. In particular, Turek $(2008$, p. 89) explains that if we consider creativity as an activity resulting in something new, unrepeatable and original, then 'teacher's performance is creative too because students are unrepeatable (there are no two equal students), teaching conditions are constantly changing, even the teacher's personality is being changed and any decision done during a teaching process should be based on these non-standard factors". According to Elder \& Paul (2006), both creativity and critical thinking are key aspects of the meaningful thinking that requires the ability to create intelligent products in a strategic way, and at the same time, they are directly linked to creativity. These are two inseparable components that are developed in parallel. All mentioned authors also highlight the necessity of their mutual integration in teaching. This argument was also one of the starting points of this research.

\section{Critical and Creative Thinking of Future Student Teachers}

Kosturkova (2017), for instance, has carried out an experimental research on critical thinking through an intervention programme which had a positive impact on a quality of asked questions by university students of various teacher study programmes. Furthermore, Kosturková (2017) has found out that the undergraduate students of various teacher study programmes evaluate the development of higher cognitive functions during their own study negatively. This fact has been confirmed by a substandard value $(\mathrm{M}=42.95)$ achieved in the Watson-Glaser Critical Thinking Appraisal. Due to this diagnostic method, the author has also found out the average value of $\mathrm{M}=$ 41.86 of students of tutoring $(\mathrm{N}=116)$ and the average value $\mathrm{M}=41.15$ of secondary school teachers $(\mathrm{N}=286)$ (Kosturková, 2013). Jurčíková (2012) reached the result of $\mathrm{M}=45.77$ on a sample of students of social pedagogy $(\mathrm{N}=54)$. Novotná, Čepelová \& Jurčíková (2015) found an average gross score in the critical thinking test $\mathrm{M}=44.55$ on a sample of students of the Faculty of Humanities in Tomas Bata University in Zlín $(\mathrm{N}=99)$.

There are also well-known findings of Maňák \& Švec (2003), in the area of the creative thinking, who have concluded that a prerequisite for developing the creativity of future teachers is the selection of suitable tasks that activate the creative potential of their personalities. Moreover, more important is also the fact that a creation of a student teacher may be developed by a motivated university teacher. Sirotová (2014, p. 44) also states that a university teacher should have the same qualities which we want an undergraduate student should develop, it means "only a creative teacher may ask his/her students to be creative, too." However, research carried out by Chmelárová (2015), where undergraduate students evaluated their former high school teachers, results that teachers almost never support a development of students' creativity. Halakova \& Kubiatko (2008) have also achieved similar findings in their research within the pre-graduate study. They assumed above a standard score of teacher trainees in natural science subjects within the creative thinking, however, their results were average. 
When talking about the relationship between critical and creative thinking, we took into granted Paul \& Elder's formulae (2006) who understand both creative and critical thinking as two key aspects of meaningful thinking that requires an ability of a strategic development of intellectual products which are directly linked to creativity. In this sense, they are two inseparably interconnected items which are being developed at the same time. Furthermore, authors emphasize the necessity of their mutual integration during a teaching process because a critical thinking without creativity is just reduced to so-called scepticism and creativity without a critical thinking reduces only to originality. Presented research has also been inspired by Duchovičová \& Tomšik (2017) and their results of the questionnaire analysis - Strategy of critical and creative thinking. Petlák (2004) points to the relationship between the level of critical and creative thinking and the study focus and he states that a content of a subject matter influences a learning process. These findings have been confirmed by, for instance, Droščák (2014) who found out that the amount of use of some activating methods (designed to support and develop the higher cognitive processes) differs to a certain extent depending on subjects, whether they are oriented in a social or natural sciences way. Based on mentioned empirical findings, a bilateral hypothesis have been formulated (taking into account that previous research did not allow precise assumption) which assumes differences in creative and critical thinking of teacher trainees of various subjects and with regard to their study programmes (social vs. natural sciences vs. a combination of programmes).

\section{Materials and Methods}

Watson-Glaser Critical Thinking Appraisal test (hereinafter W-GCTA) has been applied to map a critical thinking of teacher trainees, particularly form $\mathrm{C}$, whose authors are Watson \& Glaser (2000). W-GCTA consists of five subscales, involving eighty items. The task of a respondent is to test, assess and specify accuracy of given statements whereas it is necessary to apply analytical thinking skills. Reliability of questionnaire determined by Cronbach alpha coefficient is $\alpha=0.76$, while at the level of subscales it ranges from $\alpha=0.68$ do $\alpha=0.80$. Particular subscales of W-GCTA are defined as follows:

1) The Inference subscale discriminates among the degrees of truth and falsity of inferences drawn from given data;

2) The Recognition of Assumptions subscale recognizes unrelated assumptions on presuppositions in given statements;

3) The Deduction subscale determines whether certain conclusions necessarily follow from information given in statements or premises;

4) The Interpretation subscale weighs the evidence and determines if generalizations based on given data are warranted;

5) The Evaluation of Arguments subscale evaluates between arguments that are strong and relevant and those that are weak or irrelevant to particular questions.

Urban's Test for Creative Thinking-Drawing Production (hereinafter TSD-Z) has been applied to find out a measure of creative thinking, whose authors are Urban, Jellen \& Kováč (2002), who modified the diagnostic tool later. TSD-Z is a creative thinking divergent test designed to diagnose creative skills, some personal and cognitive dimensions. The test is based on the principles of unfinished shapes, whereas five figures are placed in a frame (semicircle, right angle, wavy line, dashed line, dot) and sixth (small "u") is located outside. A task of a respondent is to finish 
incomplete shapes. The rate of creative thinking is evaluated individually by identifying the key factors in the drawing.

\section{Research Sample}

Research sample consisted of $\mathrm{N}=317$ teacher trainees of the first year ( $\mathrm{n}=96 ; 30.3 \%$ ) and the second year $(n=221 ; 69.7 \%)$ of master study programmes at local universities - Constantine the Philosopher University in Nitra $(n=120 ; 37.9 \%)$; Matej Bel University in Banská Bystrica $(n=108$; $34.1 \%)$; Catholic University in Ružomberok $(n=89 ; 28.1 \%)$. The sample involved 103 male students $(32.5 \%)$ and 214 female students $(67.5 \%)$. Considering the research, sample differentiated according to study programmes of students, particularly humanities $(n=120)$, natural sciences $(n=86)$ and a combination of both programmes $(n=111)$. Data collection was scheduled during the first and the second quarter of 2017. Respondents' task was to fill in the questionnaire within 45 minutes.

\section{Results and Discussions}

The statistical programs IBM SPSS 20 (Statistical Package For The Social Sciences) and STATA 13 have been used to process data statistically. Further, methods of descriptive statistics to describe research data have been applied (size of a sample, median, standard deviation, standard error of the mean, skewness, and kurtosis; Tomšik, 2017). The Kolmogorov-Smirnov test of normality has been used to process data of normality within the research sample. The test confirmed the data asymmetries, therefore nonparametric tests have been used for further analysis; particularly Kruskal-Wallis comparison test and LSD (Least Significant Difference) analysis. Outcomes of descriptive statistics are displayed in Table 1, outcomes of interference statistics in Tables 2 and 3.

Table 1: Descriptive statistics and normality of research data.

\begin{tabular}{|l|l|l|l|l|l|l|l|l|}
\hline Variables & N & M & SD & SEM & S & C & KS & p \\
\hline Inference & 317 & 6.51 & 2.302 & 0.129 & 0.113 & -0.703 & 0.072 & $<0.001$ \\
\hline Recognition of Assumptions & 317 & 9.91 & 1.873 & 0.105 & -0.134 & -0.244 & 0.127 & $<0.001$ \\
\hline Deduction & 317 & 10.4 & 1.902 & 0.107 & -0.200 & -0.363 & 0.134 & $<0.001$ \\
\hline Interpretation & 317 & 10.98 & 1.888 & 0.106 & -0.246 & -0.594 & 0.135 & $<0.001$ \\
\hline Evaluation of Arguments & 317 & 9.65 & 2.071 & 0.116 & -0.176 & -0.371 & 0.106 & $<0.001$ \\
\hline W-GCTA (overall score) & 317 & 47.10 & 6.372 & 0.357 & -0.176 & -0.371 & 0.106 & $<0.001$ \\
\hline Creative thinking & 317 & 34.46 & 8.243 & 0.463 & 0.385 & -0.560 & 0.102 & $<0.001$ \\
\hline
\end{tabular}

*Note.: $N$ - the size of a sample; $M$ - median; SD - standard deviation; SEM - standard error of the mean; $S$-skewness; $C$-kurtosis; $R$-Kolmogorov-Smirnov test of normality; $p$-significance level of Kolmogorov-Smirnov test of normality.

Table 2 shows the outcomes of the comparative analysis. The results of Kruskal-Wallis test show the statistical significance level among research groups (students of humanities and natural sciences and their combinations $)$ within the creative thinking rate $(\mathrm{H}=6.590 ; \mathrm{p}=0.037)$ on the level of a significance level 0.05. Students of natural sciences subjects achieved the highest average score in the creative thinking rate $(M=35.92)$, while students of humanities achieved the lowest 
average score $(M=33.12)$. In comparison to the arithmetic mean of the whole research sample (Table 1), only the students of natural sciences achieved a higher average score in a creative thinking variable. Due to the statistical analysis, neither of variables in W-GCTA questionnaire is statistically significant in relation to the differences among research variables (Table 2)

Table 2: Comparison of research variables (W-GCTA and TSD-Z) of students considering their fields of study.

\begin{tabular}{|c|c|c|c|c|c|c|c|c|}
\hline Variables & Fields of study & $\mathbf{N}$ & $\mathbf{M}$ & SD & SEM & df & $\mathbf{H}$ & $\mathbf{p}$ \\
\hline \multirow[t]{3}{*}{ Inference } & humanities & 120 & 6.17 & 2.167 & 0.198 & \multirow[t]{3}{*}{2} & \multirow[t]{3}{*}{4.956} & \multirow[t]{3}{*}{0.084} \\
\hline & natural science & 86 & 6.53 & 2.135 & 0.23 & & & \\
\hline & combination & 111 & 6.86 & 2.526 & 0.24 & & & \\
\hline \multirow[t]{3}{*}{ Recognition of Assumptions } & humanities & 120 & 9.88 & 1.895 & 0.173 & \multirow[t]{3}{*}{2} & \multirow[t]{3}{*}{1.803} & \multirow[t]{3}{*}{0.406} \\
\hline & natural science & 86 & 9.74 & 1.81 & 0.195 & & & \\
\hline & combination & 111 & 10.9 & 1.9 & 0.18 & & & \\
\hline \multirow[t]{3}{*}{ Deduction } & humanities & 120 & 9.97 & 1.856 & 0.169 & \multirow{3}{*}{-2} & \multirow[t]{3}{*}{0.737} & \multirow[t]{3}{*}{0.692} \\
\hline & natural science & 86 & 10.12 & 2.032 & 0.219 & & & \\
\hline & combination & 111 & 10.7 & 1.862 & 0.177 & & & \\
\hline \multirow[t]{3}{*}{ Interpretation } & humanities & 120 & 10.98 & 1.789 & 0.163 & \multirow[t]{3}{*}{2} & \multirow[t]{3}{*}{0.176} & \multirow[t]{3}{*}{0.916} \\
\hline & natural science & 86 & 10.92 & 1.942 & 0.209 & & & \\
\hline & combination & 111 & 11.3 & 1.965 & 0.187 & & & \\
\hline \multirow[t]{3}{*}{ Evaluation of Arguments } & humanities & 120 & 9.3 & 1.998 & 0.182 & \multirow{3}{*}{2} & \multirow[t]{3}{*}{5.582} & \multirow[t]{3}{*}{0.061} \\
\hline & natural science & 86 & 9.84 & 2.125 & 0.229 & & & \\
\hline & combination & 111 & 9.89 & 2.073 & 0.197 & & & \\
\hline \multirow[t]{3}{*}{ W-GCTA (overall score) } & humanities & 120 & 46.27 & 6.310 & 0.576 & \multirow[t]{3}{*}{2} & \multirow[t]{3}{*}{2.004} & \multirow[t]{3}{*}{0.134} \\
\hline & natural science & 86 & 47.19 & 6.403 & 0.690 & & & \\
\hline & combination & 111 & 47.94 & 6.358 & 0.603 & & & \\
\hline \multirow[t]{3}{*}{ Creative thinking } & humanities & 120 & 33.12 & 7.736 & 0.706 & \multirow[t]{3}{*}{2} & \multirow[t]{3}{*}{6.59} & \multirow[t]{3}{*}{0.037} \\
\hline & natural science & 86 & 35.92 & 7.886 & 0.85 & & & \\
\hline & combination & 111 & 34.77 & 8.868 & 0.842 & & & \\
\hline
\end{tabular}

* Note.: $N$ - the size of a sample; $M$ - median; SD - standard deviation; SEM-standard error of the mean; $d f$-degree of free scope; $H$-Kruskal-Wallis H test; $p$-significance level.

Table 3 shows outcomes of LSD analysis. A more detailed comparison of the research groups revealed that two research groups also differ in the rate of inference - overall score of a critical thinking W-GCTA and an overall score of a creative thinking. Particularly, students of humanities achieved significantly lower average score $(\mathrm{p}=0.023)$ compared with students studying subjects in combination. Similar results were also found in the variable critical thinking, expressed by an overall score of W-GCTA. Students of humanities also achieved a significantly lower average score $(\mathrm{p}=0.047)$ compared with students studying a combination of subjects. Students of natural sciences achieved a significantly higher score in the variable creative thinking $(\mathrm{p}=0.016)$ compared with students of humanities. There were found none significant differences in other variables among research groups. 
Table 3: Comparison of research variables (Inference and TSD-Z) of students considering their fields of study: LSD analysis.

\begin{tabular}{|c|c|c|c|c|c|}
\hline Variables & Fields of study & cesearch groups) & MD & SE & $\mathbf{p}$ \\
\hline \multirow[t]{6}{*}{ Inference } & \multirow[t]{2}{*}{ humanities } & natural sciences & -0.368 & 0.324 & 0.256 \\
\hline & & combination & -0.689 & 0.302 & 0.023 \\
\hline & \multirow[t]{2}{*}{ natural sciences } & humanities & 0.368 & 0.324 & 0.256 \\
\hline & & combination & 0.321 & 0.329 & 0.33 \\
\hline & \multirow[t]{2}{*}{ combination } & humanities & -0.689 & 0.302 & 0.023 \\
\hline & & natural sciences & 0.321 & 0.329 & 0.33 \\
\hline \multirow[t]{6}{*}{ W-GCTA (overall score) } & \multirow[t]{2}{*}{ humanities } & natural sciences & -0.919 & 0.897 & 0.306 \\
\hline & & combination & -1.670 & 0.836 & 0.047 \\
\hline & \multirow[t]{2}{*}{ natural sciences } & humanities & 0.919 & 0.897 & 0.306 \\
\hline & & combination & -0.751 & 0.912 & 0.411 \\
\hline & \multirow[t]{2}{*}{ combination } & humanities & 1.670 & 0.836 & 0.047 \\
\hline & & natural sciences & 0.751 & 0.912 & 0.411 \\
\hline \multirow[t]{6}{*}{ Creative thinking } & \multirow[t]{2}{*}{ humanities } & natural sciences & -2.801 & 1.157 & 0.016 \\
\hline & & combination & -1.658 & 1.078 & 0.125 \\
\hline & \multirow[t]{2}{*}{ natural sciences } & humanities & 2.801 & 1.157 & 0.016 \\
\hline & & combination & 1.144 & 1.176 & 0.332 \\
\hline & \multirow[t]{2}{*}{ combination } & humanities & 1.658 & 1.078 & 0.125 \\
\hline & & natural sciences & -1.144 & 1.176 & 0.332 \\
\hline
\end{tabular}

*Note: $M D$ - median difference; SE - standard error; $p$ - significance level.

\section{Conclusions and Recommendations}

The main objective of research was to find out whether the level of critical thinking differs from the level of creative thinking of university students considering their fields of study. Research assumed differences in creative and critical thinking of students in the fields of humanities, natural sciences, and their combinations. There have not been identified differences in research on the level of critical thinking of university students in the fields of humanities, natural sciences, and their combinations. In comparison with other research which have been carried out (Kosturková, 2013; 2014; Jurčíková, 2012; Novotná, Čepelová \& Jurčíková, 2015) it may be stated that all results are very similar, particularly results of students of natural sciences, as well as the results in other defined groups, are not significantly different. These outcomes have been found out on the basis of LSD analysis in our research (e.g. students of humanities vs. students with a combination of study fields $\mathrm{MD}=1.670 ; \mathrm{p}=0.047$ ).

There have been found out the differences in the level of creative thinking of university students of humanities and natural sciences and their combinations. The highest ability to think creatively has been achieved by university students of natural sciences, followed by students of subjects of combinations with humanities and natural sciences, and the lowest ability of creative thinking has been achieved by students of humanities. The comparison of results in a creative thinking with the population standard (Urban, Jellen \& Kováč, 2002) shows the values oscillating between the 40th 
and 56th percentile, which are the average results. Based on the mentioned it may be stated that a creative thinking is probably not a criterion which should be decisive in selecting students-adepts for the teaching profession in a given research sample, though, the society has been demanding these requirements of a teacher's profession for a long time. In this context, a "decrease" of a level of a creative thinking from teacher trainees of natural sciences to teacher trainees of humanities may also be considered as a negative phenomenon. Creative thinking of any future teachers should be at least slightly above an average level (also so-called "a little" creativity) which should be better to develop by appropriate methods during a university study.

\section{Acknowledgements}

This work was supported by the Slovak Research and Development Agency under the contract No. APVV-15-0368.

\section{References}

[1] Č́áp, J., Mareš, J. Psychologie pro učitele. Praha: Portál, 2001.

[2] Drošćák, M.. Aktivizujúce vyučovacie metódy v praxi vyučovania strednej školy. Trnava : Univerzita sv. Cyrila a Metoda, 2014.

[3] Duchovičová, J., Tomšik, R. 2017. Stratégie kritického a tvorivého myslenia vo vyučovaní vnútorná konzistencia výskumného nástroja. Slavonic Pedagogical Studies Journal, Vol. 6, No. 2, 375-394.

[4] Duchovičová, J., Tomšik, R. Managerial Competencies of a Teacher in the Context of Learners' Critical Thinking Development: Exploratory Factor Analysis of a Research Tool and the Results of the Research. TEM Journal, Vol. 7, No. 2, 335-347.

[5] Elder, L., Paul, R. 2006. The Miniature Guide to Critical Thinking Concepts and Tools. 4th ed. [online]. The Foundation for Critical Thinking. [20. 6. 2018]. Available online: https://www.criticalthinking.org/files/Concepts_Tools.pdf

[6] Hajrová, M. Rozvoj kritického myslenia metódami aktívneho vyučovania. Osvedčená pedagogická skúsenost' edukačnej praxe. Bratislava: Metodickopedagogické centrum, 2015.

[7] Haláková, Z., Kubiatko, M. 2006. Sú budúci učitelia prírodovedných predmetov tvoriví? Pedagogika, Vol. 58, No. 1, 50-60.

[8] Chmelárová, Z. Životné cesty z pohl’adu slovenských vykokoškolákov. Media4u Magazine. Čtvrtletní časopis pro podporu vzdělávaní, Vol. 12, No. 4, 2015, 5-8.

[9] Jurčíková, J. Kritické myšlení v profesní přípravě budoucích sociálních pedagogů. Zlín: FHŠ, Univerzita Tomáše Bati ve Zlíně, 2012.

[10] Kosturková, M. Kritické myslenie pedagógov stredných škôl. Pedagogika, Vol. 4, No. 4., 2013, 283-297.

[11] Kosturková, M. 2014. Úroveň kritického myslenia študentov odboru Vychovávatel'stvo. Lifelong Learning - celoživotní vzdělávání, Vol. 4, No. 1, 2014, 45-61.

[12] Kosturková, M. Experimentálne overenie schopnosti študentov učitel’stva tvorit' otázky. Edukácia, Vol. 2, No. 1, 2017, 139-148.

[13] Maňák, J., Švec, V. Výukové metody. Brno: Paido, 2003.

[14] Novotná, J., Čepelová, S., Jurčíková, J. 2015. Critical and Creative Thinking in the Professional Preparation of Social Pedagogues. Grant Journal, Vol. 4, No.1, 2015, 81-91.

[15] Petlák, E. Všeobecná didaktika. Bratislava: IRIS, 2004.

[16] Petrasová, A. Kriticky mysliaci učitel' - tvorca kvality školy. Prešov: Rokus, 2009. 
[17] PROJEKT MILÉNIUM. Národný program výchovy a vzdelávania v Slovenskej republike. [online]. Programové vyhlásenie Vlády SR, 1998, p. 18. [20. 6. 2018]. Available online: http://www.cpk.sk/web/dokumenty/krvv.pdf

[18] Sirotová, M. Vysokoškolský učitel' v edukačnom procese. Trnava : Univerzita sv. Cyrila a Metoda, 2014.

[19] Tomšik, R. Kvantitatívny výskum v pedagogických vedách. Úvod do metodológie a štatistického spracovania. Nitra: PF UKF, 505.

[20] Turek, I. Úvod do problematiky klúčových kompetencií. Dubnica nad Váhom: Dubnický technologický inštitút, 2008.

[21] Urban, K. K, Jellen, H. K., Kováč, T. Urbanov figurálny test tvorivého myslenia. Príručka. Bratislava: Psychodiagnostika, 2002.

[22] Watson, G., Glaser, E. M. Test hodnotenia kritického myslenia. Príručka. Bratislava: Psychodiagnostika, 2000.

[23] Zelina, M. Stratégie a metódy rozvoja osobnosti diet’at’a. Bratislava: IRIS, 1996.

*Corresponding author.

E-mail address: robert.tomsik@ ukf.sk 